\title{
MENGKRITISI MAKNA HUKUM RIBA BUNGA BANK
}

\author{
Oleh : \\ Agus Sarono \\ Mahasiswa PDIH Undip
}

\begin{abstract}
Bank interest is considered usury. One is to be scrutinized if the bank interest as usury, because usury is often mentioned in the texts is characterized oppress and torment the community. As with the conventional bank interest, how many small and medium enterprises which helped because Free Master in conventional banks. Problems found in the writing of this paper is; Why people ignore the MUI fatwa on usury interest as knife analysis; Unger critical legal theory, theory of responsiveness Nonet Sezlnick, the theory of legal culture Lawrence M Friedman progressive Satjipto Rahardjo and Usul Fiqh used to find alternative meanings of texts relating to usury

From search and review of the problems concluded that after the birth of four Imam Muslim schools stuck in the mindset of the four Imams Madzhab and afraid to ijtihad. Therefore, the Muslims thought of usury is not far from what has been inferred by the four Imam mazdhab. Finally Islamic law really can not answer the development of society. Bank interest is equated with usury which both born differ in the time span, the different communities of the background, a different effect.

Therefore interest rates clearly differ from usury and should not be equated with riba. That is why people ignore the MUI fatwa in business transactions. Should the scholars 'move from positivistic Jurisprudence to understanding Sociological Jurisprudence positivistic Jurisprudence.Oleh Hence the scholars can use the legal pluralisme approach in defining legal meaning.
\end{abstract}

Keywords: Critical, Riba, Flowers Bank, Haram, Legal Theory. Usul Fiqh.

\section{PENDAHULUAN}

Pembangunan nasional dalam bidang hukum merupakan tugas berat bangsa Indonesia yang menuntut semua pihak untuk mendukungnya. Hal ini disamping konsep-konsep hukum kita masih banyak diwarisi oleh hukum kolonial, masyarakat berkembang terus. Hal ini mengharuskan pengkajian secara terus menerus apakah hukum yang ada sekarang ini masih relevan dengan kondisi zaman dan masyarakat sekarang ini. Hukum berkembang terus sesuai dengan perkembangan masyarakat dan berevolusi dalam ekonomi, politik yang berkembang. ${ }^{1}$

\footnotetext{
${ }^{1}$ Dragan Milovanivic, A primer in trhe Sociology of Law, Publisher New York.
}

Hukum yang ada sekarang ini tidak jatuh dari langit, melainkan dibangun oleh peradaban sosialnya. Tiap-tiap negara memiliki karakteristik ideologis yang berbeda dan karakteristik inilah yang akan mewarnai corak hukum yang akan dibangun. ${ }^{2}$ Oleh karena itu hukum tidak dibuat tetapi ditemukan. ${ }^{3}$

Itulah yang terjadi pada hukum riba bunga bank, pengertian riba yang turun 15 abad yang lalu disamakan dengan bunga bank di era sekarang. Pada hal keduanya

\footnotetext{
2 Suteki, Pidato Pengukuhan Guru Besar, Semarang, 4 Agustus, 2010. HIm. 11

${ }^{3}$ W Friedmann, Teori dan Filsafat Hukum, Rajawali, Jakarta. 1990.
} 
berbeda konteks yang melatar belakangi, kondisi zaman serta efeknya pada masyarakat. Ketidak patuhan masyarakat pada suatu hukum salah satu sebabnya adalah masyaraakat menganggap bahwa hukum yang berlaku itu sudah tidak memenuhi kebutuhan masyarakat. Fakta di lapangan masih banyak kita dapatakan umat Islam yang menggunakan jasa perbankan konvensional sebagai tempat transaksi bisnis. Hal ini merupakan suatu yang sangat ironis. Hukum yang seharusnya dipatuhi namun diabaikan begitu saja sehingga antara hukum dan masyarakat terpisah seakan tidak ada hubungan Oleh Karena itu pengambil keputusan, hakim dan penegak hukum yang lain harus memperhatikan the living law agar hukum dapat memenuhi rasa keadilan. ${ }^{4}$

Permasalahan yang dapat dirumuskan dalam tulisan ini adalah sebagai berikut : Mengapa masyarakat tidak patuh pada fatwa MUI bahwa bunga bank adalah riba.

\section{PEMBAHASAN}

Untuk membahas permasalahan diatas perlu disampaikan Fatwa MUI tentang Riba. Bunga adalah tambahan yang dikenakan dalam transaksi pinjaman uang (al-Qardh) yang diperhitungkan dari pokok pinjaman tanpa mempertimbangkan pemanfaatan/hasil pokok tersebut, berdasarkan tempo waktu, diperhitungkan secara pasti di muka, dan pada umumnya berdasarkan persentase.Riba adalah tambahan (ziyadah) tanpa imbalan yang terjadi karena penangguhan dalam pembayaran yang diperjanjikan sebelumnya. Dan inilah yang disebut riba nasi'ah.: Hukum Bunga Praktek pembungaan uang saat ini telah memenuhi kriteria riba yang terjadi pada zaman Rasulullah Saw, yakni riba nasi'ah.

\footnotetext{
${ }^{4}$ Suteki, Integrasi Hukum dan Masyarakat, Pustaka Magister, Semarang, 2007, hlm. 104
}

Dengan demikian, praktek pembungaan uang ini termasuk salah satu bentuk riba, dan riba haram hukumnya. Praktek pembungaan tersebut hukumnya adalah haram, baik dilakukan oleh bank, asuransi, pasar modal, pegadaian, koperasi, dan lembaga keuangan lainnya maupun dilakukan oleh individu. Untuk wilayah yang sudah ada kantor/jaringan Lembaga Keuangan Syari'ah dan mudah dijangkau, tidak dibolehkan melakukan transaksi yang didasarkan kepada perhitungan bunga. Untuk wilayah yang belum ada kantor/jaringan Lembaga Keuangan Syari'ah diperbolehkan melakukan kegiatan transkasi di lembaga keuangan konvensional berdasarkan prinsip darurat/hajat. $^{5}$

Mengapa umat Islam banyak yang menganggap bahwa bunga bank konvensional haram. ? Bagaimana menjelaskan bunga bank tidak selamanya riba ? Hal in disebabkan didalam hadist nabi menyatakan hendaknya kita patuh pada Alqur'an dan Hadist dan dijamin tidak tersesat selamanya. Ini dimaknai dengan mengikuti makna Alqur'an dan Hadist secara tekstual. Para ulama' pada umumnya masih berfikir secara positivistik melihat makna yang terlihat dan makna harfiyahnya. Hal ini disebabkan rasa patuh yang berlebihan pada Alqur'an dan Alhadist sehingga tidak berani memahami dan menggali makna yang lebih dalam karena takut keliru dan berdosa. Seharusnya para ulama harus beralih dalam memehami ayat-ayat tentang hukum dari positivistic Jurisprudence ke Sociological Jurisprudence.

Jika yang terjadi demikian maka yang terjadi umat Islam akan tersesat. Mengapa demikian. Karena hukum yang diturunkan oleh Allah dan Rasulnya merupakan jawaban terhadap situasi pada

\footnotetext{
${ }^{5}$ MUI, Fatwa Tentang Riba. Web. Internet http://www.koperasisyariah.com/fatwa-muitentang-bunga
} 
saat itu. Hukum dan masyarakat merupakan satu bingkai yang disebut " the law-society frame work" " 6 demikian Brian $\mathrm{Z}$ Tamanaha menyebutnya. Maksudnya antara hukum dan masyarakat yang melatar belakangi tidak mungkin dipisahkan.

Untuk melihat hukum riba maka harus melihat masyarakat jahiliyah pada saat ayat tersebut diturunkan. Untuk diterapkan di Indonesia pastilah memerlukan kajian lebih lanjut karena Indonesia memiliki ciri karakteristik idiologis yang berbeda dengan negaranegara lain Walaupun tidak seratus persen berbeda, namun perbedaan budaya hukum pastilah ada.

Fatwa Majelis Ulama Indonesia (MUI) tentang bunga bank mengingatkan lagi pada perdebatan panjang di antara para ulama tentang riba dan bunga bank yang sudah berlangsung beberapa puluh tahun terakhir.Dan sampai sekarang pendapat ulama masih terpecah. Belum adanya konsensus di antara para ulama seharusnya merupakan peringatan bahwa memutuskan status hukum syariah bunga bank memerlukan pengkajian yang lebih dalam. Seluruh perdebatan tentang riba dan bunga bank sebenarnya terpusat pada penafsiran para ulama terhadap dua ayat dalam AlQuran, yaitu surat 2:279 tentang larangan memungut tambahan pembayaran utang di atas jumlah pokok pinjaman, dan surat 3:130 tentang larangan memungut riba yang berlipat ganda (adz'afum mudzo'afah). Penafsiran dua ayat ini telah memunculkan dua paham yang berbeda. Golongan konservatif berpendirian bahwa riba, berapapun besarnya, tetap dilarang.Sebaliknya, golongan modernis berpendapat bahwa hanya riba yang berlipat ganda yang dilarang. Di antara dua golongan itu ada golongan ketiga yang mengambil jalan tengah. Mereka ini cukup kreatif dalam mengembangkan wacana, dan berusaha

\footnotetext{
${ }^{6}$. Tamanaha dalam Suteki,Op. Cit. HIm. 41
}

mengakomodasi penafsiran tekstual dan realitas yang berkembang di masyarakat. Pakar hukum Islam Mesir, Abdul Razzaq Sanhuri, dalam Masadir al-Haq III, misalnya, menyatakan bahwa suku bunga yang tidak berlipat ganda adalah sah menurut hukum apabila terdesak oleh kebutuhan (hajat). Ahli fikih Suriah, Doualibi, memisahkan antara pinjaman untuk keperluan produktif dan pinjaman untuk keperluan konsumtif. Bunga untuk jenis pinjaman yang pertama adalah sah, dan bunga untuk jenis pinjaman kedua tidak sah.Ada lagi yang berpendapat bahwa suku bunga yang diterima individu dari bank adalah sah, karena individu tidak bisa melakukan penindasan terhadap institusi perbankan.

Persoalan pokok dalam perdebatan ini sebenarnya adalah apakah bunga bank seperti yang kita kenal sekarang ini bisa disamakan dengan riba sebagaimana yang di maksud dalam Al-Quran. Ayat yang melarang pungutan riba yang berlipat ganda diturunkan untuk menghentikan praktek pungutan riba berlipat ganda dalam pembayaran utang, yang waktu itu meluas di kalangan masyarakat jahiliyah di Arab sebelum Islam. Praktek ini tidak lain adalah praktek rentenir dan lintah darat yang hanya menimbulkan kesengsaraan dan penderitaan yang luar biasa bagi golongan yang lemah. Riba dijadikan alat untuk pemerasan dan penindasan.

Larangan terhadap riba dikeluarkan dalam konteks dan semangat untuk mengakhiri penindasan dan untuk membebaskan golongan lemah dari penderitaan lilitan utang. Sedangkan larangan untuk memungut pembayaran utang yang melebihi nilai pokok dikeluarkan dalam konteks pesan moral AlQuran kepada umat Islam untuk menolong sesamanya. Dalam Al-Quran ditegaskan bahwa seorang muslim dilarang memungut pembayaran utang melebihi nilai pokoknya karena hal ini akan memberatkan orang yang ditolongnya. Bahkan seandainya yang punya utang tidak sanggup mengembalikan 
utang, Tuhan menganjurkan umat Islam agar merelakan piutangnya tersebut dan menjadikannya sadaqah. "Itu lebih baik bagimu, bila kamu mengetahuinya," begitu firman Allah. Maka dari itu Law and morals are related. ${ }^{7}$

Bagaimana dengan bunga bank? Di zaman modern seperti sekarang ini, suku bunga bank merupakan mekanisme pemberian imbalan dalam pasar uang sehingga dana dalam masyarakat bisa tersalur dengan efisien ke sektor-sektor yang membutuhkannya, sehingga roda perekonomian bisa berjalan dengan lancar. Penyaluran dana yang efisien berarti tersalurnya dana ke sektor-sektor ekonomi yang kegiatannya menyumbangkan secara optimal bagi pertumbuhan ekonomi.

Kehadiran bunga bank terkait dengan adanya aliran dana yang efisien dalam masyarakat. Tingkat suku bunga bank ditentukan melalui mekanisme pasar yang mengandung persaingan.Dalam merundingkan tingkat suku bunga, lembaga keuangan dan nasabahnya berada dalam kedudukan yang sama.Suku bunga bank juga merupakan salah satu instrumen bank sentral untuk menjaga stabilitas makro ekonomi satu negara.Dalam perekonomian modern, stabilitas makro ekonomi harus dijaga agar perekonomian tidak mengalami gejolak. Melalui pengendalian suku bunga inilah,bank sentral mengatasi ancaman inflasi atau resesi. Bila inflasi terlalu tinggi, bank sentral akan menaikkan suku bunga. Dan bila ekonomi mengalami resesi, bank sentral akan menurunkan suku bunga agar kegiatan ekonomi bergairah lagi. Suku bunga bank sentral yang dikenakan terhadap bank-bank komersial berfungsi sebagai acuan bagi bank-bank komersial dalam menentukan suku bunga terhadap nasabahnya.

\footnotetext{
${ }^{7}$ H.L.A. Hart, The Concept of Law, Oxford University Press, 1972
}

Peran suku bunga menjadi lebih penting lagi dalam satu perekonomian yang terbuka yang sudah terintegrasi dengan perekonomian internasional. Aliran modal yang bebas bergerak antar-negara terbukti bisa menimbulkan gejolak yang luar biasa terhadap kurs mata uang dan inflasi.Suku bunga bank berfungsisebagai salah satu instrumen yang bisa meredam gejolak ini.Begitulah di era modern ini betapa pentingnya suku bunga bank dalam perekonomian suatu negara.

Menyimpulkan bahwa suku bunga bank sama dengan riba adalah menyederhanakan persoalan dan kurang tepat karena konteks lingkungan dan hakikat keduanya sangat berbeda. Cara pandang yang menyamakan bunga bank dengan riba yang dilakukan sebagian ulama menunjukkan kurangnya pemahaman para ulama tersebut tentang sistem keuangan dan moneter. Itulah sebabnya penafsiran ayat suci akan lebih sempurna bila yang menafsirkan melengkapi diri dengan berbagai ilmu pengetahuan di luar ilmu fiqih. Oleh karena itu hukum harus merespon kenyataan sosial. Hukum tidak boleh dipaksapaksakan. Karena hukum untuk manusia bukan manusia untuk hukum ${ }^{8}$.

Pelarangan bunga bank yang didasarkan atas penafsiran ayat Alqur'an yang kurang sempurna dan yang masih bisa diperdebatkan bisa mengguncang sistem keuangan dan moneter suatu negara. Dan ini sangat berbahaya. Pertanyaan penting lain dalam perdebatan ini adalah apakah bunga bank halal. Untuk menjawabnya, kita perlu tahu apakah yang halal itu.

Yang halal adalah yang baik bagi kehidupan manusia, begitu firman Allah.

\footnotetext{
${ }^{8}$ Satjipto Rahardjo, Manusia dalam Hukum di Indonesia, Jakarta, Kompas 2004 hlm. 34 dalam Yos Johan Utama, Pidato Pengukuhan Guru Besar, 4 Februiri 2010, hlm. 13.
} 
Bunga bank telah memungkinkan pasar uang dan otoritas moneter melaksanakan fungsinya dengan baik dalam memajukan perekonomian satu negara. Melalui mekanisme bunga bank, pengusaha kecil yang biasanya selalu mengalami kesulitan modal kerja telah mendapat bantuan dari lembaga keuangan yang berfungsi dengan baik melalui mekanisme bunga bank.

Untuk menjawab pertanyaan apakah bunga bank halal harus dengan menanyakan apakah sistem keuangan dan perbankan yang ditopang sistem bunga bank seperti sekarang ini telah memberi kemaslahatan kepada kita. Dengan demikian maka pertanyaan itu sudah terjawab.

Setelah adanya empat madzhab besar yaiti Hanafi, Syafii, Hambali dan Maliki yang terjadi pada umat Islam hanya mengikuti pendapat para madzab itu. Pembahasan masalah hukum hanya pembahasan pada pemikiran Imam madzab itu. Bukan berfikir untuk menemukan hukum baru. Inilah yang dimaksud oleh Muh. Daud Ali sebagai masa kelesuan dan taklid.9 Begitu juga pemikiran-pemikiran baru tentang riba hanya berjalan ditempat (berhenti) yang ada hanya memunculkan pemikiran- pemikiran riba dari ulamaulama' yang terdahulu. Padahal Situasi dan kondisi masyarakat saat ayat tentang riba diturunkan berbeda dengan situasi dan kondisi saat sekarang ini. Kalau dulu riba dimaksudkan adalah tambahan yang menyengsarakan peminjam maka lain halnya sekarang justru dengan pinjam di bank konvensional pengusaha akan semakin kaya dengan bantuan dana pinjaman dengan sistem suku bunga. Apalagi bank konvensional milik pemerintah didirikan untuk kesejahteraan masyarakat.10

\footnotetext{
9 Mohammad Daud Ali, Hukum Islam, Raja Grafindo Perkasa Jakarta 2000. hlm.194

${ }^{10}$ Undang-Undang RI no. 7 tahun 1992. Pasal. 4
}

Tentu tidak ada alasan untuk mengatakan bahwa bunga bank konvensional itu haram. Karena ternyata bank konvensional secara prinsip pendiriannya sesuai dengan prinsi keadilan, kemanfaatan dan kesejahteran seperti yang terdapat dalam prinsip-prinsip hukum Islam 11. Itu sebabnya umat islam terjebak dalam pemikiran yang statis mengikuti pendapat yang sudah ada. Apalagi didalam Islam seorang murid harus tawadu' pada guru. Ini bukanlah nilai atau norma yang jelek namun jika diartikan tawadu' pada guru berarti harus mengikuti pemikiran gurunya maka ini yang menjadi mala petaka.

Pemikiran anti barat masih juga berada ditengah umat Islam pada umumnya. Hal ini bukan tidak beralasaan, karena setelah perang salib selesai, ternyata luka-luka lama itu belum tuntas hilang. Sentimen anti barat masih terjadi dimanamana termasuk dikalangan ilmuawan muslim. Konsep-konsep Ilmu yang datangnya dari barat dianggap haram termasuk masalah bunga bank. Itu yang dimaksud Unger bahwa, penegak hukum tidaklah netral, hukum terkait dengan politik sehingga hukum tidak dapat mencapai tujuan substantif, yang ada justru goal displacement dan goal substitution. 12 Padahal dengan kepastian suku bunga yang ditentukan oleh bank maka membuat nasabah bank membuat perhitungan dan tidak seenaknya sendiri dan membuat nasabah akan bekerja keras agar dapat mengembalikan dan bahkan bagaimana caranya agar mendapatkan laba dalam bisnisnya. Namun disisi lain dengan suku bunga belum ditentukan, rugi dan laba ditanggung bersama akan membuat nasabah kurang semangat dalam berusaha

\footnotetext{
${ }^{11}$ Muhammad Daud Ali. Op. cit. HIm. 133

12 William J. Chambliss dan Robert B. Seidman, Law, Order and Power, 1971, hlm 266-268.
} 
Seharusnya umat Islam harus fair, berfikir rasional sehingga kalau memang baik sekalipun konsep Barat seharusnya diambil kemudian kelemahannya dicari jalan keluar. Seperti untuk membantu nasabah yang terpuruk, maka sebagian laba perbankan digunakan untuk mensubsidi nasabah yang memang betul-betul jatuh.. Ini yang dimaksud dengan jangan sampai ada tudingan bahwa bunga bank itu mencekik manusia. Kalau hukum tidak diterapkan dengan melihat kondisi dan keadaan masyarakat maka hukum akan diabaikan umat manusia. Seperti contah; sekalipin ulama' kyai dan MUI menfatwakan bahwa bunga bank riba dan haram tetap juga umat Islam masih menggunakan jasa perbankan konvensional.

Natural law yang lekat dengan pertimbangan etis, moral dan agama dan pada derajat tertentu seorang akan sampai pada kesadaran yang tinggi yang disebut intuisi. Penegak hukum harus memiliki intuisi karena intuisi tidak mempertimbangkan profit oriented, like and dislike serta vested interest.13Dengan mendengarkan suara hati yang paling dalam, apakah bunga bank itu haram,tentunya dengan melihat faedah, peran, serta fungsi bunga bank di era sekarang.Pendekatan ini juga masih relevan digunakan dalam menilai bunga bank riba atau bukan.

Hukum berkembang dinamis sejalan dengan perkembangan masyarakat sehingga perlu dicari makna-makna alternatif dari riba bunga bank berdasarkan ushul fiqih.

Berangkat dari teori hukum responsif Philippe Nonet dan Philippe Selznick yang menyatakan bahwa hukum yang baik adalah hukum yang responsif terhadap kebutuan sosial dan cerdas mempertimbangkan fakta-fakta sosial dimana hukum itu berproses dan

\footnotetext{
${ }^{13}$ Suteki Op. Cit. HIm. 20.
}

diapliksikan ${ }^{14}$ Oleh karena itu tidak ada kata berhenti dalam mencari kebenaran hukum, hukum selalu berproses mencari kebenaran (searching for the truth), hukum selalu berproses, itulah yang disebut dengan hukum progresive ${ }^{15}$.Itulah yang dimaksud hukum tidak dapat dilepaskan dari masyarakat yang melatar belakangi hukum tersebut.Oleh karena itu pastilah hukum yang melarang riba tidak dapat dipisahkan dengan kondisi sosial masyarakat pada saat ayat tentang riba diturunkan.Artinya wahyu Allah pasti merespon adat kebiasaan yang ada pada saat itu.

Seperti yang telah disampaikan dimuka bahwa menurut pendapat ahli tafsir dan riwayat-riwayat tentang sebab-sebab turunnya ayat-ayat ini maka mayoritas ahli tafsir menyatkan bahwa bangsa Arab Jahiliyah biasa melakukan transaksi $i b a$, khususnya kalangan kaya. namun secara individual seperti yang terjadi pada bani Tsaqif.Merupakan hal yang tidak terpuji kalau orang kaaya memanfaatkan kesempitan orang miskin untuk memungut Riba.Dengan demikian yang menjadi Illat Hukum dari kharamnya riba adalah karena penindasan.

Banyak bukti bahwa Allah membuat suatu hukum tidak terlepas dengan masyarakat yang melatar belakangi. Begitu juga ayat tentang hukum keharaman riba. Riba dilarang oleh Allah karena kebiasaan kelompok kaya arab Jahiliyah yang biasa meminjamkan uang kepada si miskin dengan menambah bunga jika tidak dapat mengembalikan pada saat yang telah ditentukan. Akhirnya menjadi berlipat ganda hutang si miskin pada si kaya karena bunga tersebut sehingga si miskin semakin menjadi sengsara akibat hutang yang bertumpuk-

\footnotetext{
${ }^{14}$ Rafael Edi Boscue, Loc.cit

15 . Satjpito Rahardjo, Membedah Hukum

Progresef, Penerbit Buku Kompas, Jakarta, hlm. 4
} 
tumpuk, disinilah terjadi penindasan. Penindasan inilah yang sangat dilarang oleh Islam. Sehingga riba diharamkan oleh Allah dengan turunnya ayat-ayat tentang riba. Itulah kondisi masyarakat jahiliyah yang melatar belakangi haramnya hukum riba.Sekali lagi dengan berpijak pada hukum responsifnya Nonet dan Selznick yang kemudian dikuatkan dengan hukum progressif-nya Satjipto Rahardjo,maka dapat dijelaskan bahwa bank konvensional adalah lembaga keuangan yang eksist di masa modern.Dengan bank konvensional banyak orang yang terbantu dalam hidupnya.Seperti para manula yang sudah tidak mampu bekerja secara fisik maka mereka dapat menyimpan tabungannya di bank konvensional dengan menirima bunganya tanpa harus bersusah payah karena sudah tidak mampu lagi berusaha karena fisiknya yang sudah tidak menunjang. Para pengusaha baik kecil, menengah atau besar yang dapat meraih sukses dan mereka lebih sejahtera setelah mereka mendapat pinjaman modal dari bank konvensional.Artinya walaupun bank konvensional mengenakan bunga bagi yang pinjam uang namun banyak dari mereka yang meraih sukses dan lebih sejahtera.Artinya bunga bank yang ada pada bank konvensional tidak mengakibatkan penindasan dan kesengsaraan pada masyarakat justru untuk mensejahterakan masyarakat sesuai dengan tujuan didirikannya bank konvensional. Jika dicermati lebih lanjut maka pengenaan bunga kepada nasabah oleh bank

konvensional dilakukan secara terbuka dengan mengumumkan suku bunga itu kepada masyarakat,artinya bagi nasabah yang telah mengetahui suku bunga yang telah ditentukan oleh bank konvensional kemudian meminjam uang dari bank konvensional tersebut artinya mereka telah setuju dan dari pihak bank konvensional tidak memaksa apalagi menindas, artinya peminjaman uang dilakukan dengan dasar atas suka sama suka dan rela dengan suku bunga yang telah
ditentukan.Ini artinya bunga bank konvensional sangat berbeda apa yang dikenal dengan riba dijaman Jahiliyah sehingga sangat tidak masuk akal jika bunga bank konvensional disamakan dengan riba di zaman Arab Jahiliyah. Bukankah Allah memberikan kepada manusia dengn berfikir secara logis, Allah sering mengingatkan manusia untuk selalu menggunakan akal fikirannya, seperti apakah anda tidak berfikir (Afalaa tatafakkarun). Itulah yang dimaksud oleh "progessive law theory" bahwa hukum tidak pernah berhenti dalam mencari kebenran (searching for the truth), dengan demikian dapat dikatakan bahwa hukum bukan institusi mutlak dan final, karena hukum selalu berada dalam proses untuk selalu menjadi. (Law as a process, law in the making) ${ }^{16}$. Oleh karena itu dalam perspektif teori hukum progresif hukum riba yang banyak disebut oleh nash bukanlah hukum mutlak dan final tetapi dalam proses menjadi untuk mencari kebenaran.

Pandangan teori progresif itupun tidak bertentangan dengan prinsip hukum Islam yakni terus menerus berijtihad untuk mencari kebenaran. Masih dari pendapatnya Nonet dan Selznick bahwa hukum harus kompeten dan juga adil; ia seharusnya mampu mengenali keinginan publik dan punya komitment terhadap tercapainya keadilan substantif.

Pengabaian umat Islam Indonesia atas bunga bank itu haram dengan tetap menjadikan bank konvensional sebagi tempat transaksi mereka, ini berarti fatwa yang dikeluarkan MUI dan lembagalembaga Islam yang lain tidak responsif dan memiliki tendensi lain. Hukum tidak berfungsi dengan baik. Fungsi hukum

\footnotetext{
${ }^{16}$ Satjipto Rahardjo, Ibid. hlm. 6

${ }^{17}$. Suteki,Op. cit, hlm. 14
} 
sebagai social engineering tidak berjalan. Mengapa terjadi demikian. Karena bunga bank konvensional disamakan dengan riba yang terjadi pada 1400 tahun yang lalu yang memiliki kondisi sosial masyarakat yang sangat berbeda dengan kondisi sosial masyarakat saat ini. Itulah yang dimaksud dengan law as a tool of Social control dan law as a tool of Social Engineering. Jika melihat cara pandang Critical Legal Studies maka " Law is as negotiable, subjective and policydependent as politics" 18

Masih menurut pandangan CriticalLegalStudies yaitu tidak mungkin memisahkan antara masalah hukum dengan masalah-masalah politik.Oleh karena itu di dalam menganalisis masalah hokum tidak cukup dengan menganalisis hukum yang tertulis atau doktrin hukum semata tetapi harus mempertimbangkan faktor-faktor sosial politik, ekonomi yang melatar belakangi lahirnya suatu hukum.

Di Era globalisasi, hukum harus mengakomodasi isu-isu global seperti; Hak Asasi Manusia, Demokrasi, kesetaraan gender dan lain sebagainya. Jika tidak, hukum itu tidak laku dipasaran internasional apalagi isu-isu itu di munculkan oleh negara-negara maju yang memiliki kekuatan untuk menekan. Ini antara lain contoh apabila menganalisis hukum tidak cukup dengan melihat doktrin hukum saja tapi harus juga melihat kondisi sosial, politik dan ekonomi yang melatar belakangi hukum tersebut. ${ }^{19}$

Bukti-bukti lain sebagai jawaban bahwa hukum tidak boleh dianalisis hanya dengan melihat doktrin hukum saja, seperti kasus hukum yang menimpa Cholil dan Suyanto pencuri semangka dikediri yang dipidana 15 hari, dan keluarga manisih

\footnotetext{
${ }^{18}$ Ibid. hlm. 13.

${ }^{19}$ Arief Hidayat,Pidato Pengukuhan Guru Besar, 4 Februari 2010. HIm. 8
}

pencuri kapuk randu seharga Rp. 12000,di tahan selama 24 hari. Dengan dinamika masyarakat yang sangat cepat maka hukumpun harus merespon secara cepat pula, sehingga pendekatan terhadappun hukumpun harus secara variatif juga. Oleh karena itu pendekatan Legal Pluralism merupakan pendekatan hukum yang kaya akan pemaknaan. ${ }^{20}$

Kemudian untuk menjawab permasalahan yang terkait dengan metode pemaknaan alternatif dari riba bunga bank dapat digunakan metode ilmu ushul fiqih. Dengan menerapkan kaidah-kaidah pada dalil-dalil Syara' maka dapat diketahui kandungan hukumnya yang dikehendaki oleh nash. Sehingga dengan demikian dapat diperoleh hukum perbuatan dari nash tersebut. Dan dengan menerapkan kaidahkaidah tersebut dapat juga ditentukan jalan keluar (sikap) yang diambil dikala menghadapi nash-nash yang bertentangan.

Demikian juga dengan memahami ushul fiqih dapat diketahui sebab- sebab terjadinya perbedaan pendapat dikalangan ulama' perihal hukum far'i.Sebab perbedaan pendapat para ulama' dalam hukum far'iyyah disebabkan karena adanya perbedaan pendekatan dan cara yang ditempuh oleh para ulama ulama' tersebut. Dan bahkan dapat juga menyeleksi perbedaan pendapat yang ada dengan jalan memilih kaidah yang paling tepat dan yang seharusnya diterapkan.21 Seperti Kaidah yang berbunyi : "Al-amru bimaqaasidiha", yang artinya bahwa hukum itu diterapkan karena ada maksudnya. Artinya Hukum itu tidak bisa dilepaskan mengapa hukum itu diterapkan. Kaidah ini sangat tepat untuk diterapkan pada persoalan riba. Mengapa riba itu hukumnya dilarang ? Karena riba

\footnotetext{
${ }^{20}$ Suteki, Op. Cit.hlm. 43

${ }^{21}$ Kamal Muchtar dkk, Ushul Fiqih, PT. Dana Bhakti Wakaf, Yogyakarta. 1995. hlm. 6-7
} 
pada waktu itu digunakan untuk memeras serta juga menindas si miskin. Bunga bank konvensional justru sebaliknya yaitu untuk mensejahterakan masyarakat. Maka dari itu bunga bank memiliki sifat yang berlainan dengan riba meskipun ada kesamaan sifat yang lain yaitu penambahan tanpa akad riil.

Selain pendekatan kaidah ushul fiqih, juga dapat dilakukan dengan pendekatan kebahasaan (lughah). Ayat yang melarang riba dengan bahasa jangan engkau makan riba dengan berlipat ganda.(adz'afan mudlo'afan) yang artinya berlipat ganda. Artinya arti tersiratnya adalah memakan riba yang tidak berlipat ganda dan tidak menimbulkan pemerasan dan penindasan hukumnya boleh.

Nash tentang riba juga dapat didekati dengan hukum taklifi. Hukum ta'lifi berarti tuntutan hukum kepada mukallaf untuk melakukan atau tidak melakukan suatu hukum. Yang diperintahkan untuk meninggalkan riba adalah orang yang melakukan pemerasan dan penindasan kepada oarang miskin di zaman jahiliyah. Sedangkan lembaga perbankan belum ada pada saat itu sehingga lembaga perbankan tidak termasuk yang terkena hukum tersebut. Artinya dilihat dari hukum ta'lifi lembaga perbankan bukan yang dimaksud oleh nash.. Disini ulama' dapat menerapkan Judge made law seperti yang terjadi pada tradisi common law system. 22 .

\section{KESIMPULAN}

Umat Islam cenderung tidak mengikuti pendapat para ulama yang tertuang dalam fatwa MUI karena fatwa tersebut tidak sesuai dengan perkembangan zaman.Hal ini disebabkan para ulama' cenderung mengikuti pada pendapatpendapat ulama' yang terdahulu. Para ulama' memiliki pemahaman hukum yang positivistic Jurisprudence bukan

\footnotetext{
${ }^{22}$ Soetandyo Wignyosoebroto, Hukum dan

Masyarakat, Bayu Media Publishing, 2008, hIm. 41
}

Sociological Jurisprudence. Sehingga fatwa MUI belum menjawaab dinamika masyarakat.Para ulama juga tidak melakukan pendekatan legal Pluralistic terhadap hukum.

Pendakatan ushul fiqih dapat memberikan makna yang variatif dalam memahami nash tentang riba. Dengan pendekatan pendekatan kaidah ushul fiqih ditemukan makna bahwa riba yang diharamkan nash disebabkan karena riba memiliki sifat pemerasan dan penindasan sedang bunga bank tidak demikian. Dengan pendekatan bahasa (lughah) didapatkan makna bahwa riba yang diharamkan adalah riba yang berlipat-lipat (adz'afan mudlo'afan) jadi yang tidk berlipat ganda tidak termasuk yang diharamkan. Dengan pendekatan hukum taklifi, bank konvensional tidak termasuk yang terkena beban hukum. Sebab pada saat nash tentang riba turun, belum ada lembaga perbankan. Jadi dengan pendekatan ushul fiqih pemaknaan ayat riba lebih bervariatif dan menjadikan hukum Islam lebih progresif. 


\section{DAFTAR PUSTAKA}

Abu Sura'i, Abdul Hadi, 1993, Bunga Bank dalam Islam, Al Ikhlas Surabaya Indonesi.

Ali, Mohammad Daud, 2000, Hukum Islam,Raja Grafindo Perkasa Jakarta .

Antonio, Muhammad Syafi'i, 2001, Bank Syari'ah dari Teori ke Praktek, Gema Insani.

,1999, Bank Syariah, Wacana Ulama' dan Cendikia.

Al-Qardhawi, Yusuf.2001, Bunga Bank Haram,Media Eka Sarana.

Arifin, Miftahul, dkk, 1997, Ushul Fiqih, Citra Media, Surabaya.

Ash Shiddieqy, Hasbi, dalam Nazar Bakri, 1986, Ushul Fiqih, PT. Raja Grafindo Persada.

Biek, Syekh. Muh. Khudhori, 1982, Ushul Fiqih, Raja Murah Pekalongan.

Boscu, Rafael Edy (penerjemah),1978,Law \& Society in Tradition: Toward Responsive Law,Philippe Nonet \& Philip Selznick,Perkumpulan Untuk Pembaharuan Hukum

Berbasis Masyarakat dan Ekologis.

Eugene, Bardach, Can Network Theory Illuminate Interagency Collaboration. 1994.

Friedman,Lawrence M.,,2009, The Legal System: A Social Science Perspective, Terj. M Khozim"Sistem Hukum:Perspectif Ilmu Sosial" Bandung: Nusa Media.

Friedmann,W, Teori dan Filsafat Hukum, Rajawali, Jakarta. 1990.
Hart, H.L.A. The Concept of Law, Oxford University Press, 1972.

Hasbullah, Jousairi, 2006, Social Capital (Menuju Keunggulan Budaya Manusia Indonesia),

Penerbit. MR-United Press Jakarta.

Ifdhal, Kasim, 1999, Gerakan Studi Hukum Kritis (Roberto Mangabaira Unger,Lembaga Studi dan Advokasi Masyarakat. Jakarta.

Kamal, Muchtar dkk,1995, Ushul Fiqih, PT. Dana Bhakti Wakaf, Yogyakarta.

Milovanivic,Dragan, A primer in trhe Sociology of Law, Publisher New York

Rahardjo,Satjipto, Membedah Hukum Progresef, Penerbit Buku Kompas, Jakarta..

Rasyidi, Lili, Hukum Sebagai Suatu Sistem, Remaja Rosdakarya, Bandung, 1993.

Salim, Agus, 2001, Teori daan Paradigma Penelitian Sosial (dari ,Guba dan Wacana. Penerapannya),Tiara

Soemitro, Ronny Hanityo, Study Hukum dan Masyarakat, Alumni, Bandung.

Suteki, 2007, Integrasi Hukum dan Masyarakat, Pustaka Magister, Semarang

, Hukum dan Kebijakan Publik, Pustaka Magister, Semarang, 2007. 
HUMANIKA Vol. 21 No. 1 (2015) ISSN 1412-9418

Mengkritisi Makna Hukum Riba Bunga Bank

Agus Sarono

---------, Kedudukan Sociological Jurisprudence DALAM Ilmu Hukum, Media Hukum, Semarang, 2009.

Tamanaha, Brian Z., A general Jurisprudence of Law and Society, Oxford University Press, New York, 2006.

Umam, Chairul ,dkk. 1998, Ushul Fiqih 1, Pustaka Setia, Bandung.
Wahhab Khallaf, Abdul, 1972, Ushul Fiqih, Dina Utama, Semarang.

Wignyosoebroto, Soetandyo,Hukum dalam Masyarakat, Bayu Media Publishing, 2008.

--------, Paradigma, Metode dan Dinamika Masalahnya, Eslam dan Hurna Jakarta, $\quad .2002$.

William J. Chambliss dan Robert B. Seidman, Law, Order and Power, 1971.

\section{PERATURAN PERUNDANG-UNDANGAN DAN KITAB SUCI.}

Undang-Undang RI no. 7 tahun 1992

Depag.1995. Alqur'an dan Terjemahnya,

\section{MAKALAH :}

Arief, Nawawi Barda, Makalah Seminar, FH UNDIP. 2009

Hidayat, Arief, Pidato Pengukuhan, 4 Februari 2010.

Suteki, Pidato Pengukuhan, 4 Agustus 2010.

Utama, Yos Johan, Pidato Pengukuhan, 4 Agustus 2010.

\section{INTERNET.}

MUI,http/www. fatwa-mui-tentang-bunga.

Penelitian di Sumatra Barat, http//www.bi.go.id

Info Nasabah,http//www.infobanknews.com. 